\title{
PERANAN KEPALA SEKOLAH DALAM MENINGKATKAN POTENSI GURU MELALUI BIMBINGAN PEMBUATAN MEDIA PEMBELAJARAN DARI LIMBAH ANORGANIK
}

\author{
Ade Neni Suryani \\ TK Budi Asih VI Majalengka, Indonesia \\ ade.suryani321@gmail.com
}

\begin{abstract}
The principle of education in kindergarten that is learning while playing, so, learning resources or media used for learning in children must refer to these principles. However, efforts to develop learning media by teachers are often hampered by funding problems. One way that can be done is to use used materials or waste. On this basis the authors conducted research with the aim of increasing the potential of teachers in developing learning media. The method used in this study is the School Action Research (PTS) method with a qualitative approach. PTS is a research procedure adapted from Classroom Action Research (CAR). PTS is carried out in two cycles. The results of the study show that providing guidance can improve the ability of teachers in making recycling media from organic waste. Thus it can be concluded the role of the head of kindergarten in guiding teachers can develop the ability of teachers so that the impact on children's learning outcomes increases.
\end{abstract}

Keywords: Guidance, school principals, learning media, inorganic waste.

\section{ABSTRAK}

Prinsip pendidikan di Taman Kanak-kanak yakni belajar sambil bermain, sehingga, sumber belajar atau media yang digunakan untuk pembelajaran pada anak harus mengacu pada prinsip tersebut. Namun upaya pengembangan media pembelajaran oleh guru sering kali terbentur masalah dana. Salah satu cara yang dapat dilakukan adalah dengan memanfaatkan bahan bekas atau limbah. Atas dasar itulah penulis melakukan penelitian dengan tujuan meningkatkan potensi guru dalam mengembangkan media pembelajaran. Metode yang digunakan dalam penelitian ini adalah metode Penelitian Tindakan Sekolah (PTS) dengan pendekatan kualitatif. PTS merupakan suatu prosedur penelitian yang diadaptasi dari Penelitian Tindakan Kelas (PTK). PTS ini dilaksanakan dalam dua siklus. Hasil penelitian menunjukan pemberian bimbingan dapat meningkatkan kemampuan guru dalam pembuatan media daur ulang dari limbah organik. Dengan demikian dapat disimpulkan peranan kepala TK dalam dalam membimbing guru dapat mengembangkan kemampuan guru sehingga berdampak pada hasil belajar anak meningkat.

Kata Kunci: bimbingan, kepala sekolah, media pembelajaran, limbah anorganik.

Submitted Feb 2, 2020 | Revised Feb 18, 2020 | Accepted Feb 26, 2020

\section{Pendahuluan}

Salah satu komponen yang harus dicapai pada anak usia Taman Kanak-kanak adalah membentuk peserta didik yang harmonis dengan memperhatikan kebutuhan serta perkembangan anak. Selain itu, mengacu pada prinsip pendidikan di Taman Kanak-kanak yakni belajar sambil bermain. Hal ini dengan tujuan agar seluruh aspek perkembangan pada anak usia dini dapat tercapai (Holis, 2016). Dengan demikian maka sumber belajar atau media yang digunakan untuk pembelajaran pada anak harus mengacu pada prinsip tersebut. Kreativitas guru dalam menyediakan dan memanfaatkan media pembelajaran yang inovatif dan 
berdayaguna masih kurang optimal. Akibatnya, proses pembelajaran kurang menarik dan kreativitas siswa menjadi kurang berkembang. dan pemanfaatan media pembelajaran oleh guru sering kali terbentur masalah dana. Oleh karena itu diperlukan jalan keluar yang kreatif adalah dengan mengembangkan media sederhana di lingkungan sekitar.

Guru sebagai garda terdepan di bidang pendidikan, harus terus melakukan pengembangan diri secara berkelanjutan agar menjadi guru yang mampu menghasilkan sumber daya manusia yang berkualitas (Nahdi \& Cahyaningsih, 2019). Guru yang inovatif, sebenarnya banyak cara yang dapat dilakukan dengan memberdayagunakan bahan bekas atau sampah yang dapat diambil di lingkungan sekolah, seperti bungkus jajanan anak, plastik-plastik bekas makanan (limbah anorganik) dll, yang dapat dimanfaatkan oleh guru sebagai alat pembelajaran atau dibuat alat peraga, sampah dapat menjadi sesuatu yang berguna sehingga bermanfaat untuk mengurangi penggunaan bahan baku yang baru. Beberapa studi yang dilakukan oleh Siarni, dkk (2015), Kusnafizal dan Nursamsu (2017), serta Agustina dan Sunarso (2018) menunjukkan media dari barang bekas mampu meningkatkan hasil dan prestasi belajar siswa. Bahan bekas yang di daur ulang memiliki kelebihan atau segi positif yaitu dari segi ekonomi harga yang murah dan mudah didapat dengan mudah di sekitar kita. Selain itu, kita juga dapat mengurangi tumpukan sampah yang ada di lingkungan sekolah dengan cara mendaur ulang barang tersebut.

kepala sekolah adalah salah satu komponen pendidikan yang paling berperan dalam meningkatkan kualitas pendidikan (Mulyasa, 2007). Atas dasar itu, maka kepala sekolah harus mampu berperan dalam mendorong para guru untuk mampu mengembangkan media pembelajaran dari barang-barang bekas. Kepala sekolah adalah guru yang diberi tugas tambahan untuk memimpin dan mengelola sekolah. Dalam Peraturan Pemerintah Nomor 38 Tahun 1992, pasal 20 ayat 1 menyatakan bahwa, "Kepala sekolah adalah tenaga kependidikan yang ditugaskan untuk bekerja sebagai pengelola satuan pendidikan dan pengawas pada jenjang pendidikan dasar dan menengah dipilih dari kalangan guru". Dengan pernyataan lain, kepala sekolah adalah guru yang mendapatkan tugas tambahan sebagai pengelola satuan pendidikan.

Secara garis besar, ruang lingkup tugas kepala sekolah dapat diklasifikasikan ke dalam dua aspek pokok, yaitu pekerjaan di bidang administrasi sekolah dan pekerjaan yang berkenaan dengan pembinaan profesional kependidikan. Sebagai pelaksana, perencana, seorang ahli, mengawasi hubungan antara anggota-anggota, menwakili kelompok, bertindak sebagai pemberi ganjaran, bertindak sebagai wasit, pemegang tanggung jawab, sebagai seorang pencipta, dan sebagai seorang ayah.” (Purwanto, 2004) Untuk melaksanakan tugas tersebut dengan sebaik - baiknya, ada tiga jenis ketrampilan pokok yang harus dimiliki oleh kepala sekolah sebagai pemimpin pendidikan yaitu ketrampilan teknis (technical skill), ketrampilan berkomunikasi (buman relations skill) dan ketrampilan konseptual (conceptual skill).

Menurut persepsi banyak guru, keberhasilan kepemimpinan kepala sekolah terutama dilandasi oleh kemampuannya dalam memimpin. Kunci bagi kelancaran kerja kepala sekolah terletak pada stabilitas dan emosi dan rasa percaya diri. Hal ini merupakan landasan psikologis untuk memperlakukan stafnya secara adil, memberikan keteladanan dalam bersikap, bertingkah laku dan melaksanakan tugas.

Berbagai upaya telah dilakukan Kepala Sekolah untuk meningkatkan kemampuan guru terutama dalam proses pembelajaran, antara lain pemberian motivasi agar guru memperdalam pengetahuan bidang studi yang harus dikuasai, memberikan bimbingan terhadap guru dengan 
memperdalam pengetahuan tentang berbagai sumber belajar serta media pembelajaran yang dapat digunakan oleh guru. Namun fokus perbaikan yang dilakukan dalam penelitian ini adalah meningkatkan kualitas pembelajaran inovatif guru khususnya dalam menggunakan media pembelajaran daur ulang limbah anorganik, media daur ulang limbah anorganik ini menjadi salah satu solusi dalam menjawab permasalahan minimnya dana yang tersedia untuk pembuatan media pembelajaran, karena media daur ulang limbah anorganik ini minim biaya serta berdayaguna tinggi.

Ada beberapa manfaat media yang lebih rinci. Kemp dan Dayton (1985) mengidentifikasi beberapa manfaat media dalam pembelajaran, yaitu :

a) Penyampaian materi pelajaran dapat diseragamkan.

b) Proses pembelajaran menjadi lebih jelas dan menarik.

c) Proses pembelajaran menjadi lebih interaktif.

d) Efisien dalam waktu dan tenaga.

e) Meningkatkan kualitas hasil belajar siswa.

f) Media memungkinkan proses belajar dapat dilakukan di mana saja dan kapan saja.

g) Media dapat menumbuhkan sikap positif siswa terhadap materi dan proses belajar.

h) Mengubah peran guru ke arah yang lebih positif dan produktif

Adapun tujuan penelitian ini adalah untuk meningkatkan kemampuan guru melalui pembuatan dan penggunaan media daur ulang limbah anorganik di TK Budi Asih VI Kelurahan Sindangkasih, manfaat media dalam proses pembelajaran adalah memperlancar interaksi antara guru dengan siswa sehingga kegiatan pembelajaran akan lebih efektiff dan efisien

Tetapi secara lebih khusus ada beberapa manfaat media yang lebih rinci. Kemp dan Dayton (1985) misalnya, mengidentifikasi beberapa manfaat media dalam pembelajaran, yaitu :

a) Penyampaian materi pelajaran dapat diseragamkan.

b) Proses pembelajaran menjadi lebih jelas dan menarik.

c) Proses pembelajaran menjadi lebih interaktif.

d) Efisien dalam waktu dan tenaga.

e) Meningkatkan kualitas hasil belajar siswa.

f) Media memungkinkan proses belajar dapat dilakukan di mana saja dan kapan saja.

g) Media dapat menumbuhkan sikap positif siswa terhadap materi dan proses belajar.

h) Mengubah peran guru ke arah yang lebih positif dan produktif

Daur ulang adalah salah satu strategi pengelolaan sampah padat yang terdiri atas kegiatan pemilahan, pengumpulan, pemrosesan, pendistribusian dan pembuatan produk / material bekas pakai, dan komponen utama dalam manajemen sampah modern dan bagian ketiga adalam proses hierarki sampah 3R (Reuse, Reduce, and Recycle).

Limbah adalah bahan sisa yang dihasilkan dari suatu kegiatan dan proses produksi, baik pada skala rumah tangga, industri, pertambangan, dan sebagainya.

Limbah anorganik adalah limbah yang tidak bisa diuraikan oleh proses biologi. Limbah ini tidak dapat diuraikan oleh organisme detrivor atau dapat diuraikan tetapi dalam jangka waktu yang lama. Limbah ini tidak dapat membusuk, oleh karena itu dapat dijadikan sampah komersil atau sampah yang laku dijual untuk dijadikan produk lainnya. 
Limbah anorganik yang dapat di daur ulang, antara lain adalah plastik, logam, dan kaca. Namun, limbah yang dapat didaur ulang tersebut harus diolah terlebih dahulu dengan cara sanitary landfill, pembakaran (incineration), atau penghancuran (pulverisation).

Akibat dari limbah seperti ini (plastik, styrofoam, dll) adalah menumpuk semakin banyak dan menjadi polutan pada tanah misalnya, selain menggangu pemandangan.

Adapula limbah anorganik yang berasal dari kegiatan rumah tangga seperti botol plastik, botol kaca, tas plastik, kaleng dan aluminium.

Berdasarkan beberapa definisi di atas, dapat disimpulkan bahwa media daur ulang limbah organik adalah media yang dibuat dari limbah organik yang di daur ulang. Dalam penelitian ini, limbah organik yang didaur ulang seperti plastik bekas bungkus jajanan anakanak yang berserakan di lingkungan TK.

\section{Metode Penelitian}

Metode yang digunakan dalam penelitian ini adalah metode Penelitian Tindakan Sekolah (PTS). Pendekatan yang digunakan dalam penelitian tindakan ini ialah pendekatan kualitatif. Artinya, penelitian ini dilakukan karena ditemukan permasalahan rendahnya tingkat kedisiplinan guru dalam kehadiran dikelas pada proses kegiatan belajar mengajar. Permasalahan ini ditindaklanjuti dengan cara menerapkan sebuah model pembinaan kepada guru berupa penerapan Reward dan Punishment yang dilakukan oleh kepala sekolah, kegiatan tersebut diamati kemudian dianalisis dan direfleksi. Hasil revisi kemudian diterapkan kembali pada siklus-siklus.

Menurut Kunandar (2008:65) pentingnya PTK bagi guru adalah: (1) Membuat guru peka dan tanggap terhadap dinamika pembelajaran di kelas; (2) Meningkatkan kinerja guru, (3) Guru mampu memperbaiki proses pembelajaran melalui suatu kajian yang dalam terhadap apa yang terjadi di kelas; (4) Dengan melaksanakan PTK berarti guru telah menerapkan pengajaran yang reflektif, artinya guru secara sadar, terencana, dan sistematis melakukan refleksi atau perenungan terhadap kegiatan pembelajaran yang telah dilakukan.

Pada penelitian ini menggunakan media siklus menurut Kemmis (dalam Bidayah, 2019). Model siklus menurut Kemmis sebenarnya hampir sama dengan yang lain akan tetapi, proses tindakan dan observasi dijadikan satu. Penelitian tindakan kelas ini didasarkan pada permasalahan yang dihadapi guru dalam kegiatan belajar mengajar. Untuk mengetahui kekurangan selama proses pembelajaran di kelas, peneliti memerlukan bantuan pengamat/observer dalam melakukan penelitian.

Langkah-langkah penelitian tindakan sekolah dapat digambarkan seperti gambar dibawah ini : 


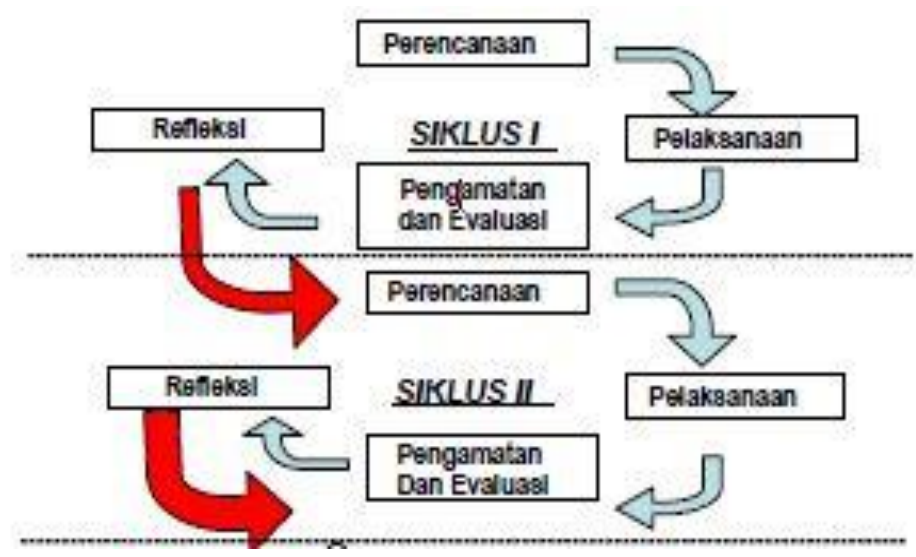

Gambar 1. Model PTS Kemmis dan Mc Taggart

Tindakan yang dilakukan dalam penelitian ini adalah pemberian bimbingan terhadap guru-guru dalam penggunaan media daur ulang limbah anorganik yang akan digunakan dalam proses pembelajaran. Diharapkan dengan pemberian bimbingan yang diberikan oleh Kepala Sekolah ini dapat meningkatkan kemampuan yang dimiliki guru terutama dalam pembuatan media yang digunakan dalam pembelajaran, agar pembelajaran tidak monoton dan lebih bervariasi.

Metode pengumpulan data yang diambil oleh penulis merupakan data kualitatif melalui observasi, pengamatan serta catatan yang diperoleh dari hasil refleksi yang dilakukan melalui kegiatan diskusi antara Kepala Sekolah dengan guru.

Pelaksanaan penelitian tindakan sekolah ini dilaksanakan melalui beberapa kegiatan, antara lain :

a) Pengumpulan guru-guru TK Budi Asih VI Kelurahan Sindangkasih dalam sebuah ruangan sebagai tempat pemberian bimbingan dalam pengembangan media daur ulang dari limbah anorganik.

b) Kepala Sekolah memberikan penjelasan mengenai pentingnya media sebagai alat atau sarana dalam menyampaikan pembelajaran pada siswa yang mana akan membuat proses pembelajaran menjadi lebih menarik dan bervariasi sehingga anak tidak merasa jenuh dan monoton.

c) Kepala Sekolah memberikan beberapa materi dalam proses bimbingan pada guru-guru. Kegiatan bimbingan tersebut dilakukan dalam dua kali pertemuan kepada setiap guru selama dua minggu (satu siklus).

d) Setelah pemberian bimbingan melalui penjelasan dan penegasan, Kepala Sekolah kemudian membimbing guru-guru TK Budi Asih VI dalam mengembangkan media daur ulang dari limbah anorganik, yakni dalam proses pembuatan medianya.

e) Proses pembuatan media tersebut berlangsung selama satu minggu yang kemudian Kepala Sekolah akan memberikan penilaian terhadap hasil karya guru dalam pembuatan dan pengembangan media daur ulang dari limbah anorganik.

\section{Hasil dan Pembahasan}


Penelitian Tindakan Sekolah (PTS) ini dilaksanakan dalam dua siklus. Hal ini dikarenakan keterbatasan waktu yang tersedia, serta dengan dua siklus sudah penulis anggap cukup untuk peningkatan kemampuan guru dalam penggunaan media daur ulang limbah anorganik pada kegiatan belajar mengajar.

\section{Siklus 1}

Siklus 1 terdiri atas beberapa tahap, yaitu : (1) Perencanaan, (2) Pelaksanaan, (3) Pengamatan dan Evaluasi, dan (4) Refleksi. Peneliti juga melakukan penilaian terhadap kemampuan guru dalam menggunakan media dan mengaplikasikannya dalam proses mengajar, indikator penilaiannya meliputi menarik dan kaya aksi, membangun pemahaman secara konkret dan verbalistik serta bersifat sederhana dan praktis digunakan.

Dari hasil pengamatan pada siklus I mengenai pembuatan media daur ulang dari limbah organik yang dilakukan oleh guru, hasil penilaiannya adalah sebagai berikut:

Tabel 1 Penilaian untuk Pembuatan Media

\begin{tabular}{lcccc}
\hline No & Nama & $\begin{array}{c}\text { Sesuai dengan tujuan } \\
\text { yang dicapai }\end{array}$ & $\begin{array}{c}\text { Hasil Pengamatan } \\
\text { Ekonomis } \\
\text { mudah diperoleh }\end{array}$ & $\begin{array}{c}\text { dan } \\
\text { kebuai dengan }\end{array}$ \\
\hline 1 & Yayah & 50 & 50 & 50 \\
2 & Ela & 50 & 53 & 48 \\
3 & Tati & 53 & 50 & 49 \\
4 & Asri & 50 & 47 & 53 \\
5 & Uum & 47 & 50 & 50 \\
6 & Widiyani & 48 & 49 & 47 \\
7 & Tuti & 49 & 48 & 50 \\
\multicolumn{7}{r}{ Humlah Skor } & 362 & 362 & 362 \\
\multicolumn{7}{r}{ Hasil Yang Diharapkan } & $80 \%$ & $51,7 \%$ & $51,7 \%$ \\
\hline
\end{tabular}

Dari data diatas dapat ditarik kesimpulan bahwa presentase rata-rata penilaian pembuatan media daur ulang dari limbah organik yang dilakukan oleh guru hanya $51,7 \%$.

Selain penilaian dalam pembuatan media daur ulang anorganik, Peneliti juga melakukan penilaian dalam penerapan dan penggunaan media daur ulang dari limbah organik, adapun hasil penilaiannya adalah sebagai berikut:

Tabel 2 Penilaian untuk Penggunaan Media

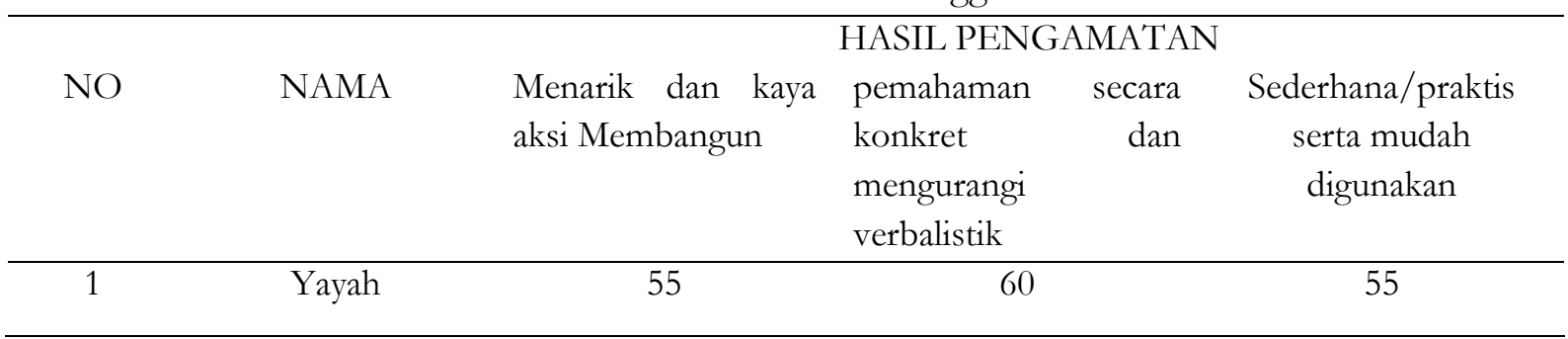


20 Suryani, Peranan Kepala Sekolah Dalam Meningkatkan Potensi Guru...

\begin{tabular}{lcccc}
\hline 2 & & & & \\
3 & Ela & 50 & 60 & 60 \\
4 & Tati & 55 & 50 & 55 \\
5 & Asri & 60 & 60 & 60 \\
6 & Uum & 55 & 60 & 55 \\
7 & Widiyani & 55 & 50 & 55 \\
& Tuti & 50 & 50 & 50 \\
\multicolumn{2}{r}{ Hasil Yang Diharapkan } & 380 & 390 & 390 \\
& \% Skor & $80 \%$ & $54,3 \%$ & $54,3 \%$ \\
\hline
\end{tabular}

Jumlah presentase dari hasil penilaian peneliti terhadap penggunaan media daur ulang limbah organik yang telah dibuat sebesar $54,3 \%$. Berdasarkan indikator yang telah ditetapkan bahwa keberhasilan tindakan ini adalah $80 \%$, atau bila $80 \%$ rata-rata presentase hasil penilaian terhadap guru dalam penggunaan media. Sehingga, dalam pemberian tindakan ini belum mencapai indikator keberhasilan.

Berdasarkan data pada tabel di atas, penilaian untuk pembuatan media daur ulang limbah organik, secara keseluruhan mendapatkan rata-rata penilaian sebesar 51,7\%. Jumlah presentase dari hasil penilaian peneliti terhadap penggunaan media daur ulang limbah organik yang telah dibuat sebesar $54,3 \%$. Adapun data tersebut dapat disajikan pada tabel

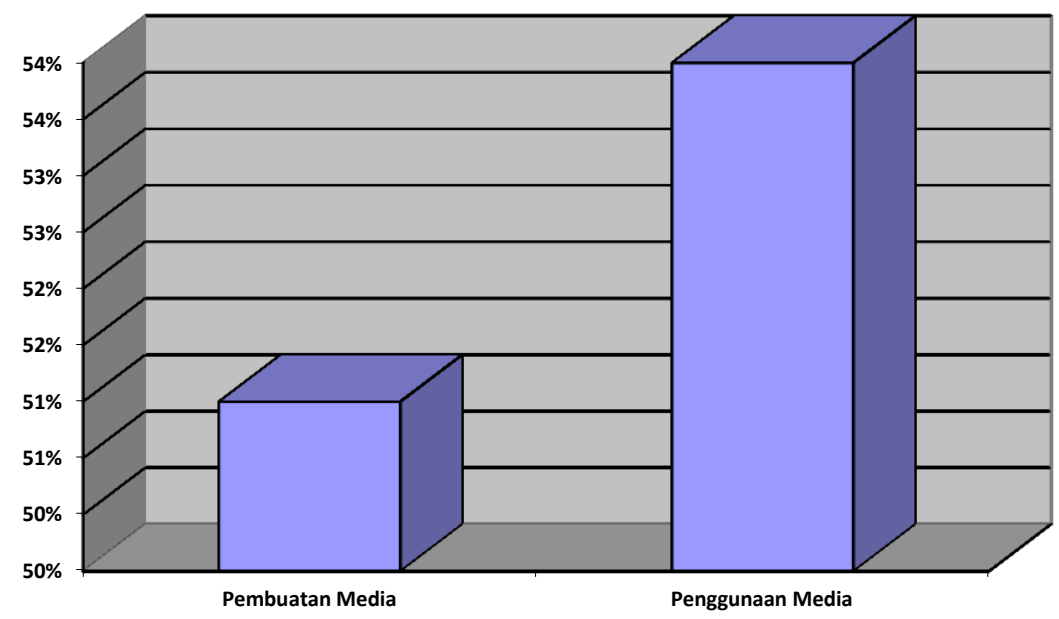

Gambar 2 gambar grafik penilaian guru

Dari grafik di atas, dalam penggunaan media daur ulang limbah organik memiliki presentase kecil yaitu 54,3\% yang mana masih jauh dari indikator keberhasilan yang sudah ditetapkan sebelumnya yakni $75 \%$. Selain itu kecilnya presentase mengenai penilaian dalam penggunaan media disebabkan karena media yang dibuat pun masih memiliki beberapa kekurangan terutama dalam komponen dalam penilaian sehingga menghasilkan penggunaan media yang kurang juga. Dikarenakan hasil penilaian yang belum mencapai indikator 
keberhasilan yakni 75\%, jadi peneliti berkesimpulan harus diadakan penelitian atau tindakan lagi pada siklus berikutnya atau siklus kedua.

Setelah selesai satu siklus maka diadakan refleksi mengenai kelemahan atau kekurangan dari pelaksanaan tindakan pada siklus pertama. Refleksi dilaksanakan bersama-sama kolaborator untuk menentukan tindakan perbaikan pada siklus berikutnya. Dari hasil refleksi dapat diambil suatu kesimpulan bahwa perlu pemberian bimbingan yang lebih mendalam dalam perbaikan dari media daur ulang limbah organik agar lebih sempurna lagi daripada siklus pertama terutama dalam memenuhi kriteria yang terdapat pada indikator penilaian sehingga akan berdampak pada proses implementasi atau penerapannya.

\section{Siklus 2}

Siklus 2 terdiri atas beberapa tahap, sama seperti siklus 1 yaitu : (1) Perencanaan, (2) Pelaksanaan, (3) Pengamatan, dan (4) Refleksi.

Dari hasil refleksi pada siklus pertama, peneliti merencanakan untuk melakukan tindakan pemberian bimbingan yang lebih mendalam dibandingkan dengan siklus pertama. Peneliti merencanakan untuk mengumpulkan kembali guru-guru TK Budi Asih VI untuk diberikan kembali bimbingan yang lebih luas dan mendalam dalam perbaikan media daur ulang dari limbah organik yang telah dibuat serta bimbingan dalam proses penerapan media tersebut.

Adapun elaksanaan penelitian tindakan sekolah pada siklus yang kedua ini dilaksanakan melalui beberapa kegiatan, antara lain :

a. Pengumpulan guru-guru TK Budi Asih VI Kelurahan Sindangkasih kembali untuk pemberian bimbingan dalam perbaikan media daur ulang dari limbah anorganik serta bimbingan kembali dalam proses penerapannya.

b. Sebelum masuk dalam proses bimbingan kembali, Kepala Sekolah membuka sesi diskusi untuk para guru agar guru-guru dapat sharing apa yang menjadi kendala dan hambatan dalam pengembangan media dan penggunaannya.

c. Berdasarkan kendala dan hambatan yang dimiliki guru, Kepala Sekolah memberikan bimbingan dengan menekankan pada perbaikan media daur ulang yang dibuat dari segi kesesuaian dengan kebutuhan siswa dan juga keterkaitannya dengan tujuan yang akan dicapai, karena kedua indikator tersebut masih dalam kategori kurang sehingga harus diperbaiki komponen dari media daur ulang limbah anorganik yang telah dibuat.

d. Selain itu, Kepala Sekolah memberikan bimbingan dalam penggunaan media yang telah diperbaiki untuk membuat media tersebut menarik perhatian anak yang ditambah dapat membangun pengetahuan dan pemahaman anak.

Dari hasil pengamatan pada siklus II mengenai pembuatan media daur ulang dari limbah organik yang dilakukan oleh guru, hasil penilaiannya adalah sebagai berikut:

Tabel 3. Penilaian untuk Pembuatan Media

\begin{tabular}{ccccc}
\hline NO & NAMA & $\begin{array}{c}\text { Sesuai dengan tujuan } \\
\text { yang dicapai }\end{array}$ & $\begin{array}{c}\text { HASIL PENGAMATAN } \\
\text { Ekonomis dan mudah } \\
\text { diperoleh }\end{array}$ & $\begin{array}{c}\text { Sesuai dengan } \\
\text { kebutuhan siswa }\end{array}$ \\
\hline 1 & Yayah & 85 & 84 & 85 \\
2 & Ela & 86 & 85 & 87 \\
\hline
\end{tabular}


22 Suryani, Peranan Kepala Sekolah Dalam Meningkatkan Potensi Guru...

\begin{tabular}{|c|c|c|c|c|}
\hline 3 & Tati & 84 & 86 & 86 \\
\hline 4 & Asri & 85 & 86 & 86 \\
\hline 5 & Uum & 86 & 85 & 87 \\
\hline 6 & Widiyani & 87 & 87 & 85 \\
\hline \multirow[t]{3}{*}{7} & Tuti & 87 & 87 & 84 \\
\hline & lah Skor & 600 & 600 & 600 \\
\hline & $\%$ & $85,7 \%$ & $85,7 \%$ & $85,7 \%$ \\
\hline \multicolumn{2}{|c|}{ Hasil Yang Diharapkan } & $80 \%$ & $80 \%$ & $80 \%$ \\
\hline
\end{tabular}

Dari data diatas dapat ditarik kesimpulan bahwa presentase rata-rata penilaian perbaikan dalam pembuatan media daur ulang dari limbah organik yang dilakukan oleh guru meningkat dari 51,7\% menjadi $\mathbf{8 5 , 7 \%}$. Berarti ada peningkatan sebanyak $\mathbf{3 4 \%}$ dari siklus I ke siklus II.

Selain penilaian dalam pembuatan dalam perbaikan media daur ulang anorganik, Peneliti juga melakukan penilaian dalam penerapan dan penggunaan media daur ulang dari limbah organik, adapun hasil penilaiannya adalah sebagai berikut:

Tabel 4 Penilaian untuk Penggunaan Media

\begin{tabular}{|c|c|c|c|c|}
\hline \multirow{3}{*}{$\mathrm{NO}$} & \multirow{3}{*}{ Nama } & \multicolumn{3}{|c|}{ Hasil Pengamatan } \\
\hline & & \multirow[t]{2}{*}{$\begin{array}{l}\text { Menarik dan kaya } \\
\text { aksi Membangun }\end{array}$} & $\begin{array}{lr}\text { pemahaman } & \text { secara } \\
\text { konkret } & \text { dan }\end{array}$ & $\begin{array}{c}\text { Sederhana/praktis } \\
\text { serta mudah }\end{array}$ \\
\hline & & & mengurangi verbalistik & digunakan \\
\hline 1 & Yayah & 89 & 90 & 89 \\
\hline 2 & Ela & 88 & 89 & 89 \\
\hline 3 & Tati & 87 & 88 & 88 \\
\hline 4 & Asri & 86 & 86 & 87 \\
\hline 5 & Uum & 88 & 88 & 86 \\
\hline 6 & Widiyani & 86 & 87 & 88 \\
\hline 7 & Tuti & 88 & 86 & 86 \\
\hline & Jumlah Skor & 612 & 614 & 613 \\
\hline & $\%$ & $88 \%$ & $88 \%$ & $88 \%$ \\
\hline & Hasil Yang & $80 \%$ & \multirow[t]{2}{*}{$80 \%$} & $80 \%$ \\
\hline & Diharapkan & & & \\
\hline
\end{tabular}

Jumlah presentase dari hasil penilaian peneliti terhadap penggunaan media daur ulang limbah organik yang telah diperbaiki sebesar $\mathbf{8 8 \%}$. Terjadi peningkatan dalam penggunaan dan penerapan media daur ulang limbah anorganik dari siklus I ke siklus II yaitu adanya

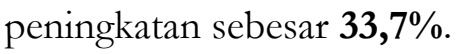


Berdasarkan data pada tabel di atas, penilaian untuk pembuatan media daur ulang limbah organik, secara keseluruhan mendapatkan rata-rata penilaian sebesar 85,7\%. Jumlah presentase dari hasil penilaian peneliti terhadap penggunaan media daur ulang limbah organik yang telah dibuat sebesar $88 \%$. Adapun data tersebut dapat disajikan pada tabel berikut:

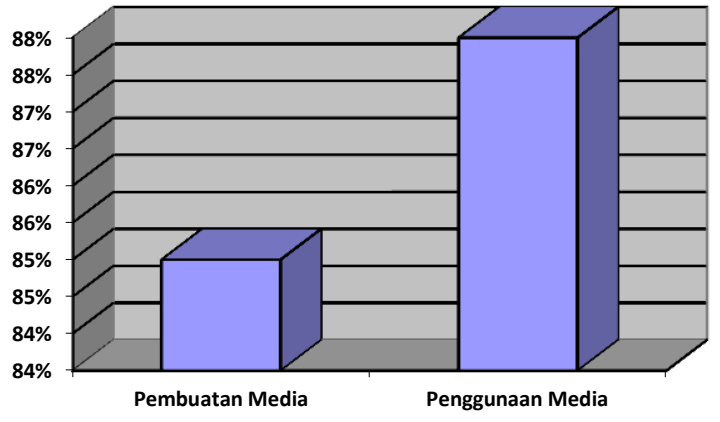

Gambar 3. Penilaian Pembuatan Media

Setelah selesai pelaksanaan tindakan pada siklus kedua maka diadakan refleksi mengenai kelemahan atau kekurangan dari pelaksanaan tindakan pada siklus kedua tersebut. Dari hasil observasi dan data yang diperoleh, peneliti mengambil kesimpulan bahwa tindakan yang dilaksanakan pada siklus kedua dinyatakan berhasil, karena terdapat terjadi peningkatan dalam pembuatan media daur ulang limbah organik melalui proses perbaikan, yakni dari 51,7\% menjadi 85,7\%. Berarti ada peningkatan sebanyak 34\% dari siklus I ke siklus II. Selain itu peningkatan juga terjadi pada proses penggunaan media yakni menjadi 88\% dari yang sebelumnya 54,3\%, atau melebihi target yang telah ditentukan sebesar 80\%. Sehingga pemberian tindakan siklus kedua ini penulis merasa puas karena telah mencapai indikator keberhasilan. Untuk lebih jelasnya dapat dilihat pada grafik berikut :

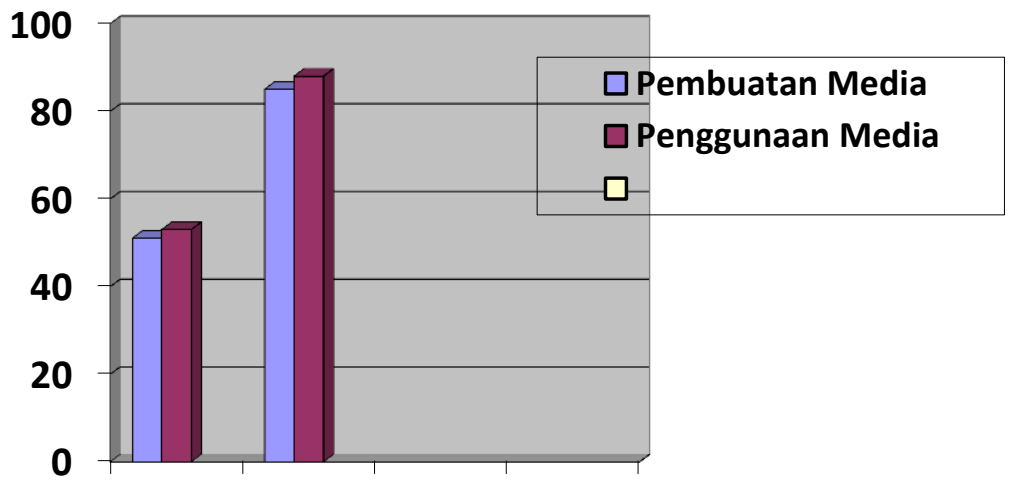

Siklus I Siklus II

Gambar 4 Hasil Pengamatan Siklus I dan Siklus II

Dari gambar di atas, maka hasil pengamatan peranan kepala TK dalam Meningkatkan kemampuan guru melalui pemberian bimbingan pada pengembangan media daur ulang limbah anorganik, dapat terliaht dari siklus I, ke siklus II menunjukkan peningkatan yang signipikan, ketecapaian hasil pembelajaran sesuai dengan yang diharapkan, maka peranan kepala TK dalam dalam membimbing guru dapat mengembangkan kemampuan guru sehingga hasil belajar anak meningkat. 


\section{Kesimpulan}

Dari seluruh tindakan yang telah dilaksanakan dalam dua siklus, dapat disimpulkan bahwa pemberian bimbingan dapat meningkatkan kemampuan guru dalam pembuatan media daur ulang dari limbah organik yakni dari 51,7\% menjadi 85,7\%. Selain itu, melalui proses bimbingan, peningkatan juga terjadi pada proses penggunaan media yakni menjadi $88 \%$ dari yang sebelumnya $54,3 \%$, atau melebihi target yang telah ditentukan sebesar $75 \%$.

\section{Daftar Pustaka}

Agustina, R \& Sunarso, A. (2018). Pemanfaatan Barang Bekas Sebagai Media Peningkatan Kreativitas Pada Mata Pelajaran SBK. Joyful Learning Journal, 7 (3), 75-79.

Anwar, Moch. (2004). Administrasi Pendidikan dan Manajemen Biaya Pendidikan. Bandung: Alfabeta.

Bidayah, I. (2019). Upaya Meningkatkan Kemampuan Belajar Siswa Melalui Pendekatan Keterampilan Proses. Jurnal Educatio, 5(2), 107-114

Hartini, Tri. (2013). Peranan Kepala Sekolah, Guru, dan Guru Pembimbing dalam Implementasi Kurikulum 2013 untuk Peningkatan Mutu Pendidikan. [Online] Tersedia: http://prosiding.upgrismg.ac.id/index.php/FIP13/fip013/paper/viewFile/266/213

Holis, A. (2016). Belajar Melalui Bermain untuk Pengembangan Kreativitas dan Kognitif Anak Usia Dini. Jurnal Pendidikan Universitas Garut, 9(1), 23-37.

Kunandar (2009). Langkah Mudah Penelitian Tindakan Kelas Sebagai Pengembangan Profesi Guru. Jakarta: Rajawali Pers

Kusnafizal \& Nursamsu. (2017). Penerapan Pembuatan Media Pembelajaran Dari Bahan Bekas Melalui MGMP Biologi Tingkat SMA Sederajat Kabupaten Aceh Tamiang. Jurnal Pendidikan Biologi, 6(3), 356-360.

Mulyasa. (2007). Standar Kompetensi dan Sertifikasi Guru. Bandung: PT. Remaja. Rosdakarya.

Nahdi, D.S. \& Cahyaningsih, U. (2019). Keterampilan Guru SD Dalam Menghadapi Era Revolusi Industri 4.0. Social, Humanities, and Educational Studies (SHEs): Conference Series, 57-63.

Purwanto, N. (2002). Administrasi Dan Supervisi Pendidikan, Bandung: PT. Remaja Rosdakarya.

Sapari, Achmad. (2002). Pemahaman Guru Terbadap Inovasi Pendidikan.Artikel. Jakarta: Kompas.

Siarni, dkk. (2015). Pemanfaatan Barang Bekas Sebagai Media Pembelajaran Untuk Meningkatkan Hasil Belajar IPA Siswa Kelas IV SDN 07 Salule Mamuju Utara. Jurnal Kreatif Tadulako Online, 3(2), 94-104.

Undang-Undang Republik Indonesia Nomor 20 Tahun 2003 tentang Sistem Pendidikan Nasional

Undang-Undang Republik Indonesia Nomor 14 Tahun 2005 tentang Guru dan Dosen. 